\title{
Histopathology and immunohistochemistry of the caecum in children with the Trichuris dysentery syndrome
}

\author{
T T MacDonald, M-Y Choy, J Spencer, P I Richman, T Diss, B Hanchard, \\ $S$ Venugopal, D A P Bundy, E S Cooper
}

\begin{abstract}
Caecal biopsy specimens from Jamaican children with the Trichuris dysentery syndrome (TDS) and age matched Jamaican controls were investigated by immunohistochemistry and by light microscopy. Biopsy specimens from all children (with TDS and controls) showed a mild to moderate increase in inflammatory cells. Except in the vicinity of the worm, where the epithelium was flattened, there was no other epithelial abnormality. Compared with controls, children with TDS had increased IgM lamina propria plasma cells and decreased intraepithelial $T$ cells. There was also an increase in crypt epithelial cell proliferation. Lamina propria $T$ cells (both activated and non-activated) were no more common in children with the Trichuris syndrome than controls. Epithelial cell HLA-DR and VLA-1 expression (which are increased in other colitides) were the same in both groups. Despite the presence of large worm burdens and chronic dysentery, therefore, only minor changes were seen in the caecal mucosa of children with TDS.
\end{abstract}

Trichuris trichiura is a nematode parasite of the human colon. It occurs throughout the world but is more common in the Tropics. In light infections worms are found only in the colon, but in heavier infections all of the colon and rectum can be colonised. Intense infection (greater than 200 worms) is more common in children between the ages of 2 and 10 years and is associated with a colitis termed the "Trichuris dysentery syndrome" (TDS). ${ }^{1-3}$ Affected children pass frequent, bloody, heavily mucoid stools, may present with rectal prolapse, and are often severely growth retarded. ${ }^{4}$ Antihelminthic treatment eliminates the worms, restores normal colonic function, and leads to a rapid growth spurt. ${ }^{4}$

Chronic diarrhoea and growth suppression are also associated with the idiopathic colitides and enteropathies such as Crohn's disease and ulcerative colitis in children in the developed world. $^{56}$ In these diseases the mucosal inflammatory responses are well characterised. To our knowledge, however, there is little information on the histology of the colon in chronic trichuriasis. This is of interest because, unlike the idiopathic colitides, the agent responsible for the Trichuris dysentery syndrome is known. We describe here the histopathology and immunohistology of the caecum in the Trichuris dysentery syndrome.

\section{Methods}

Colonic (caecal) : biopsy specimens were obtained at colonoscopy from children with a clinical history suggestive of TDS. ${ }^{2}$ The study was approved by the ethical committee of the University of the West Indies and the biopsy specimens were taken at the Tropical Metabolism Research Unit, University of the West Indies, Jamaica.

The study was carried out in two parts. Firstly, caecal plasma cell numbers were measured on a group of five children with TDS (cases 5-9) (table 1) and four age matched controls (cases 1-4 (table 1)). This part of the study was carried out using formalin fixed, paraffin wax embedded caecal biopsy specimens. Sections $4 \mu \mathrm{m}$ thick were cut, dewaxed, and $\operatorname{IgA}$, IgM, IgG plasma cells

Table 1 Patient details

\begin{tabular}{|c|c|c|c|}
\hline Case No & Age & Sex & \\
\hline A Controls & & & Diagnosis \\
\hline $\begin{array}{l}1 \\
2 \\
3 \\
4\end{array}$ & $\begin{array}{l}5 \cdot 9 \\
2 \cdot 5 \\
4 \cdot 2 \\
1 \cdot 7\end{array}$ & $\begin{array}{l}M \\
F \\
F \\
M\end{array}$ & $\begin{array}{l}\text { Normal } \\
\text { Non-specific colitis } \\
\text { Mild proctitis } \\
\text { Normal. }\end{array}$ \\
\hline $\begin{array}{l}\text { Patients } \\
5 \\
6 \\
7 \\
8 \\
9\end{array}$ & $\begin{array}{l}4 \cdot 5 \\
3 \cdot 8 \\
2 \cdot 6 \\
6 \cdot 6 \\
5 \cdot 7\end{array}$ & $\begin{array}{l}\mathbf{M} \\
\mathbf{M} \\
\mathbf{F} \\
\mathbf{M} \\
\mathbf{F}\end{array}$ & $\begin{array}{l}\text { Worm burden } \\
932 \\
988 \\
391 \\
3543 \\
2700\end{array}$ \\
\hline B Controls & & & Diagnosis \\
\hline $\begin{array}{l}1 \\
2 \\
3 \\
4 \\
5 \\
6\end{array}$ & $\begin{array}{l}2 \cdot 2 \\
4 \cdot 0 \\
4 \cdot 9 \\
5 \cdot 0 \\
2 \cdot 7 \\
7 \cdot 1\end{array}$ & $\begin{array}{l}\mathbf{F} \\
\mathbf{F} \\
\mathbf{M} \\
\mathbf{M} \\
\mathbf{F} \\
\mathbf{M}\end{array}$ & $\begin{array}{l}\text { Non-Trichuris dysentery } \\
\text { Proctitis } \\
\text { Non-Trichuris dysentery } \\
\text { Polyps } \\
\text { Rectal prolapse } \\
\text { Small bowel disease }\end{array}$ \\
\hline Patients & & & Worm burden \\
\hline $\begin{array}{r}7 \\
8 \\
9 \\
10 \\
11 \\
12 \\
13 \\
14 \\
15 \\
16 \\
17\end{array}$ & $\begin{array}{l}6 \cdot 3 \\
3 \cdot 2 \\
2 \cdot 5 \\
5 \cdot 0 \\
2 \cdot 9 \\
5 \cdot 0 \\
3 \cdot 0 \\
4 \cdot 3 \\
3 \cdot 2 \\
3 \cdot 2 \\
4 \cdot 6\end{array}$ & $\begin{array}{l}\mathbf{F} \\
\mathbf{F} \\
\mathbf{M} \\
\mathbf{M} \\
\mathbf{F} \\
\mathbf{F} \\
\mathbf{F} \\
\mathbf{M} \\
\mathbf{F} \\
\mathbf{F} \\
\mathbf{F}\end{array}$ & $\left.\begin{array}{r}893 \\
1535 \\
\star \star \\
\star \star \\
1275 \\
1904 \\
715 \\
970 \\
720 \\
942 \\
1431\end{array}\right\}$-twins \\
\hline
\end{tabular}

* Stools were not collected for these children after anthelminthic treatment, but large numbers of worms were visible in the caecum at colonoscopy. 
Table 2 Details of monoclonal antibodies used

\begin{tabular}{lll}
\hline Antibody & Specificity & Source \\
\hline UCHT1 & CD3 & ICRF-HTIG, \\
1B5 & HLA-DR & ICniversity College Hospital, London \\
Leu 3a & CD4 & Becton Dickinson Ltd, \\
Leu 2a & CD8 & Mountain View, California \\
TCR $\delta 1$ & $\gamma \delta$ TcR & T Cell Sciences, \\
Anti-VLA-1 & VLA-1 $\alpha$ chain & Cambridge, MA \\
Ki67 & Dividing cells & Dako Ltd, \\
Anti-Tac & CD25 & Wigh Wycombe, Bucks \\
\hline
\end{tabular}

identified by immunoperoxidase immunohistochemistry as described elsewhere. ${ }^{7}$ The antisera used were isotype specific, affinity purified, rabbit antisera purchased from Dako Ltd, High Wycombe, Buckinghamshire. A peroxidase conjugated goat anti-rabbit IgG (Dako Ltd) was used as a second layer.

Frozen sections were used in the second part of the study. This permitted the use of a greater number of phenotypic markers. Biopsy specimens obtained at colonoscopy were snap frozen in liquid nitrogen and stored at $-70^{\circ} \mathrm{C}$. Tissue was studied from 11 children with trichuriasis (cases 7-17) (table 1) and six controls (cases 1-6) (table 1). Cryostat sections $6 \mu \mathrm{m}$ thick were cut and stained using the alkaline phosphatase anti-alkaline phosphatase (APAAP) method, as described previously. ${ }^{7}$ The APAAP technique was used because endogenous peroxidase in inflammatory cells in the mucosa of both groups of patients made immunoperoxidase stained sections impossible to interpret. The monoclonal antibodies used in this study are shown in table 2 . Secondary antibody used was a rabbit anti-mouse IgG (Dako Ltd) and the monoclonal APAAP antibody used was also purchased from Dako Ltd. Fast red was used to visualise antibody binding.

Immunostained plasma cells, $\mathrm{CD} 3+$, or $\mathrm{CD} 25+$ cells in the lamina propria were counted as the percentage of stained cells of the total number of nucleated cells in the lamina propria. At least 500 cells were counted in each biopsy specimen. Differences between group means were determined by analysis of variance.

The relative numbers of cells expressing CD3, CD4, CD8, or $\gamma \delta \mathrm{TcR}$ in the caecal epithelium were quantified by counting the number of positively stained cells in a given length of epithelium (both surface and crypt). Length of epithelium was measured with a calibrated micrometer eyepiece. At least 200 positively stained lymphocytes were counted in each biopsy specimen. Differences between group means were determined by analysis of variance.

HLA-DR and VLA-1 staining of epithelial cells was graded semi-quantitatively on a four point scale $( \pm,+,++$, or +++$)$. The range of staining was from very weak cytoplasmic and basolateral membrane staining $( \pm)$ to intense cytoplasmic and membrane staining $(+++)$. For statistical analysis the grades were converted to numbers $(t=0.5,+=1,++=2$, and $+++=3$ ), and the groups were compared using the Kolmogorov-Smirnov 2 group test.
Ki67 staining of dividing crypt epithelial cells was carried out as described previously. ${ }^{8}$ Differences between group means were determined by analysis of variance. Where applicable results are shown as mean \pm 1 standard error.

\section{Results}

HISTOPATHOLOGICAL FINDINGS

Haematoxylin and eosin stained sections of caecal biopsy specimens from nine children (five with Trichuris and four controls (table 1)) were coded and examined blind by one of us (PIR). All biopsy specimens showed a mild to moderate increase in chronic inflammatory cells in the lamina propria. In sections where worms were visible epithelial cells were distorted adjacent to the worm, but otherwise there was no evidence of architectural damage or active cryptitis. In biopsy specimens from both normal controls and childred infected with Trichuris there was occasional mild goblet cell depletion. The colon of a patient with trichuriasis is shown in fig 1 . Specimens from the transverse colon, descending colon, and rectum of children with TDS were also examined and showed the same histological features as those of caecal mucosa.

Plasma cell numbers in the lamina propria The percentage of plasma cells containing $\operatorname{IgM}, \operatorname{IgG}$, and IgA were determined in caecal

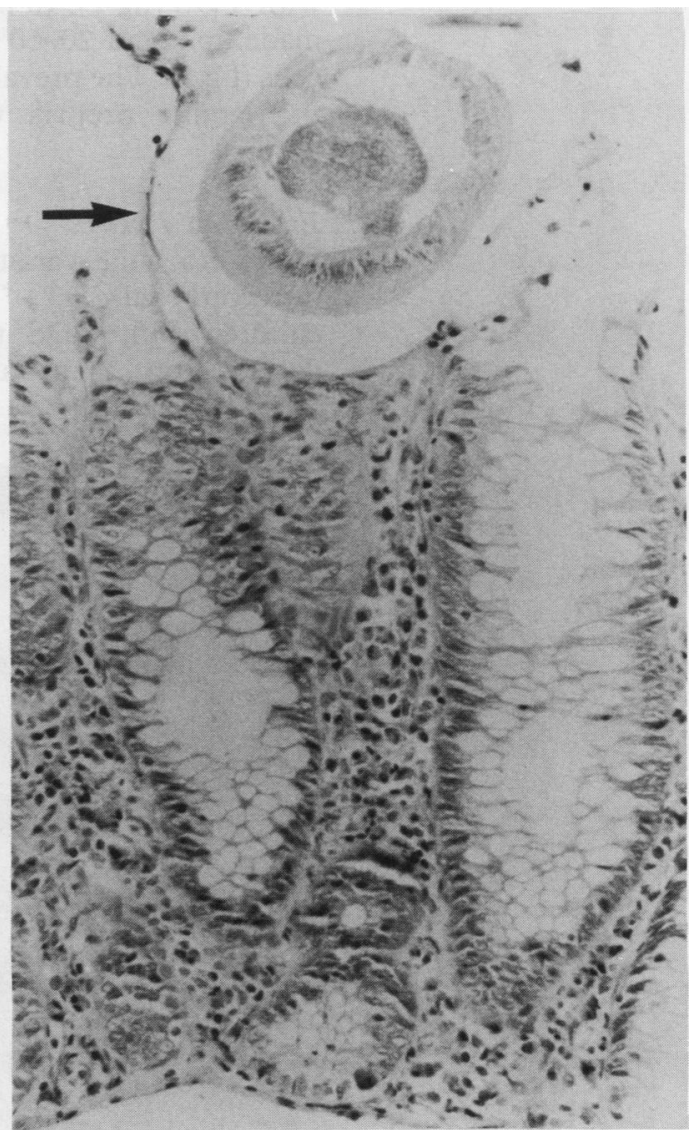

Figure 1 Histological appearance of the caecal mucosa in a child with trichuriasis. Although there is an increase in lamina propria inflammatory cells, the glands are long and straight and well filled with goblet cells. Note epithelial synctium (arrow) forming around the head of the worm (haematoxylin and eosin). 
Table 3 Plasma cells in caecal lamina propria

\begin{tabular}{llll}
\hline \multirow{4}{*}{\multicolumn{4}{l}{ \% Lamina propria cells }} \\
\cline { 2 - 4 } & \multicolumn{1}{l}{ Plasma cell isotype } \\
\cline { 2 - 4 } & $\operatorname{Ig} A$ & $\operatorname{Ig} M$ & $\operatorname{IgG}$ \\
\hline Controls & $26 \cdot 3(6 \cdot 4)$ & $7 \cdot 2(3 \cdot 0)$ & $6 \cdot 2(3 \cdot 0)$ \\
Patients & $34 \cdot 8(5 \cdot 3)$ & $12 \cdot 3(3.9)^{\star}$ & $3 \cdot 7(3 \cdot 1)$ \\
\hline
\end{tabular}

${ }^{\star} p<0.05$ compared with IgM in controls (pooled estimate of variance).

biopsy specimens from four controls and five children with TDS (table 3 ). IgA positive plasma cells predominated in both groups. IgM positive plasma cells were more abundant than IgG plasma cells. There were significantly more IgM plasma cells in the caecum of the children with TDS than controls.

Lamina propria $C D 3+$ and $C D 25+T$ cells CD3 + cells were counted to establish if worm infection was associated with an increase in the density of lamina propria $T$ cells. Those cells expressing CD25 (the $\beta$ chain of the IL-2 receptor) were also quantified to determine if any lamina propria cells were activated. CD25 is expressed on activated $\mathrm{T}$ cells and macrophages; but these two cell types can be differentiated as the CD25 + macrophages are usually large, foamy cells which predominate in the subepithelial layer. ${ }^{9}$ There were no differences in the prevalence of CD3 + and CD25 + cells in the lamina propria of controls and children with TDS (fig 2). In both groups $\mathrm{CD} 3+$ cells made up about $20-60 \%$ of the lamina propria cells (fig 3). The prevalence of CD25 + cells in the lamina propria varied widely in both groups.

Epithelial T cells

Despite a wide variation in the numbers of intraepithelial $\mathrm{CD} 3+\mathrm{T}$ cells in the controls, in children with TDS there was a significant decrease in their number (fig 4). Most

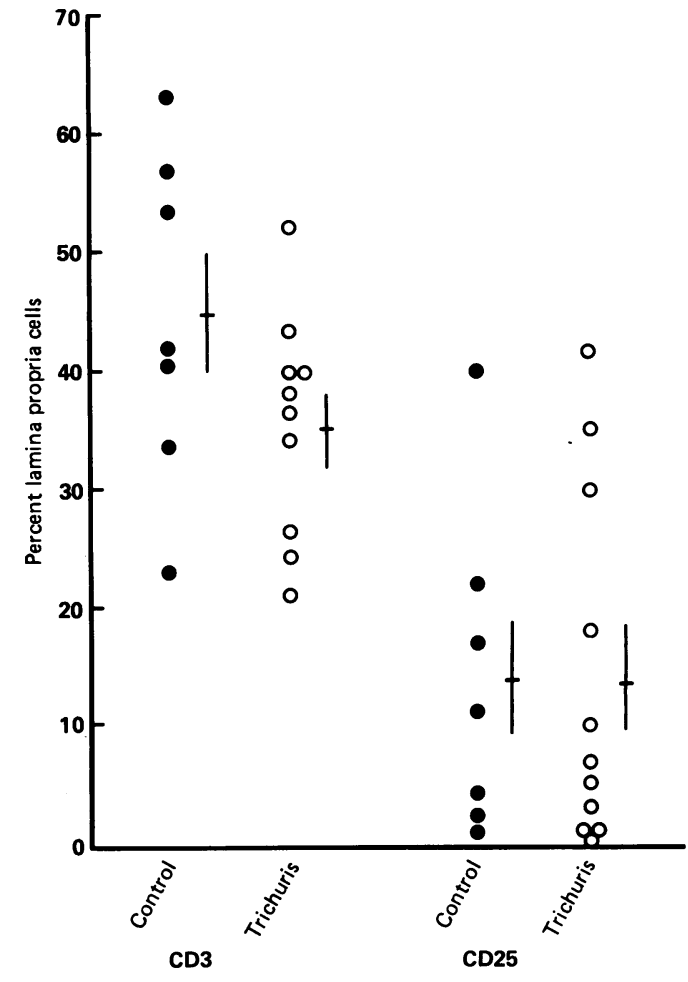

Figure 2 The percentage of lamina propria cells expressing $C D 3$ or $C D 25$ in controls or children with TDS. Although there is a wide range in both groups, no differences are apparent.

intraepithelial lamina cells are CD8 + and as expected, there was also a decrease in epithelial CD8 + intraepithelial cells in TDS. CD4+ intraepithelial cells were rare in both groups. $\gamma \delta$ $\mathrm{TcR}+$ intraepithelial cells were also decreased in patients with TDS. This result also shows that most of the CD3 + cells in the colon use the $\alpha \beta$ TcR.

$H L A-D R$ and $V L A-1$ expression on epithelium The epithelial expression of HLA-DR and VLA-1 can be used as an index of colonic

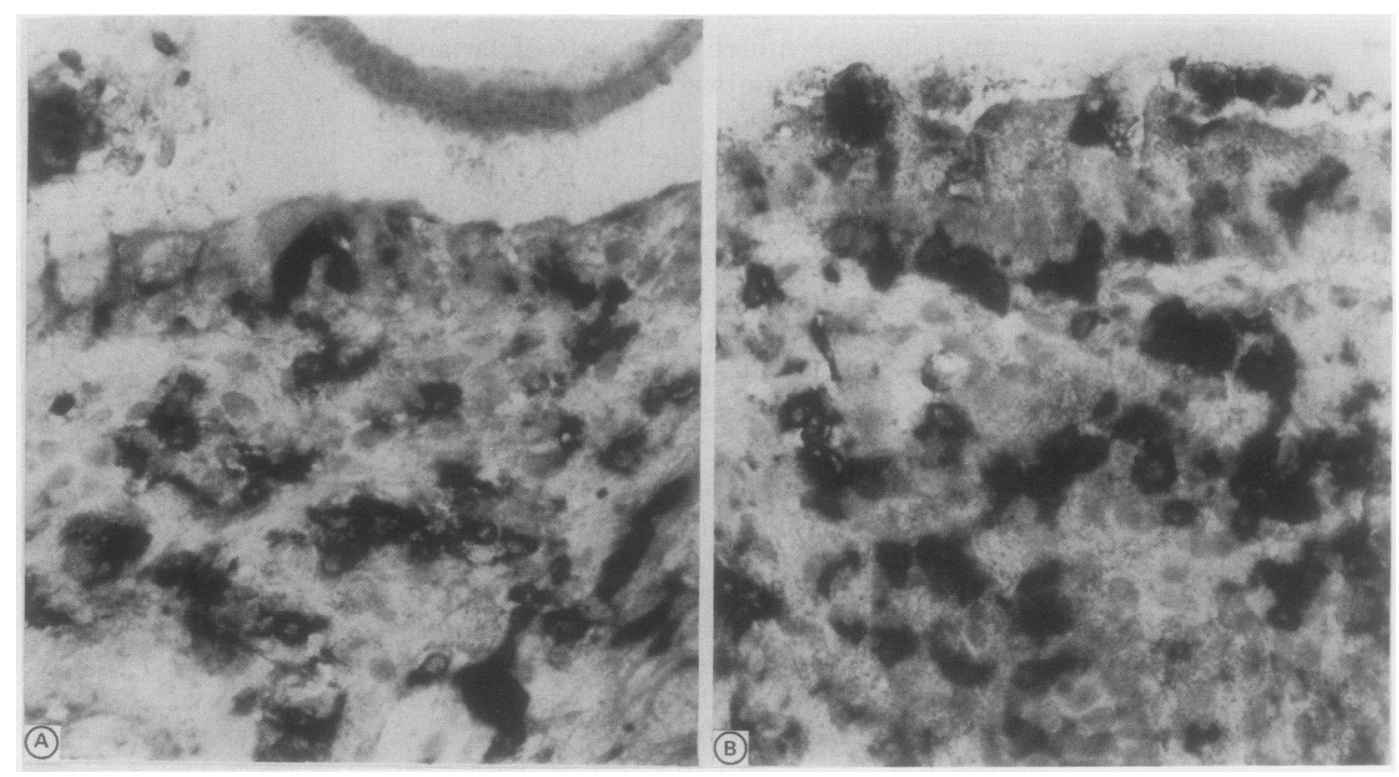

Figure 3 (A) CD3 $+T$ cells in the lamina propria and epithelium immediately below a worm ( $A P A A P)$ (B) $C D 3+T$ cells in the lamina propria and epithelium of a control child ( $A P A A P)$. 
Figure 4 Numbers of epithelial $T$ cells are reduced in children with TDS.

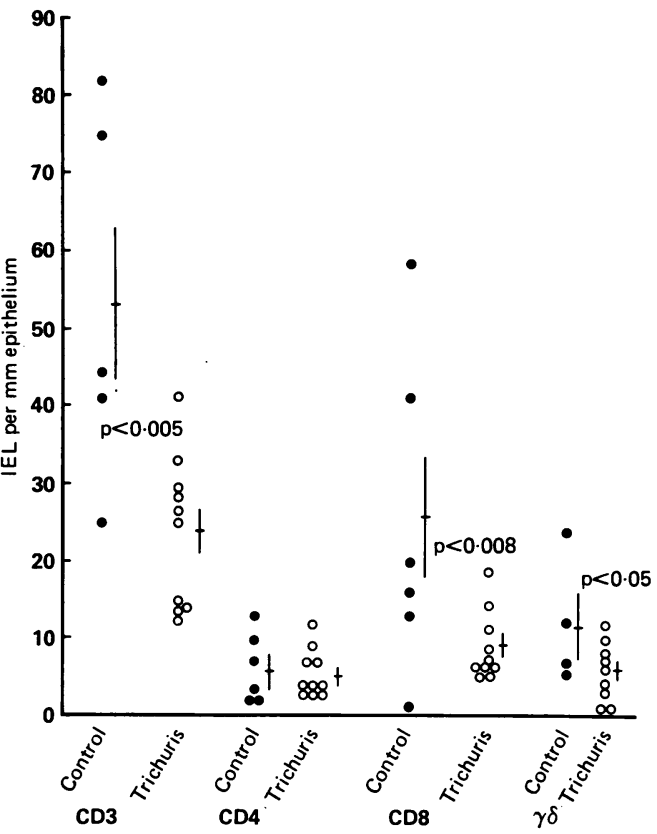

inflammation. ${ }^{10-13}$ As expected, HLA-DR expression was absent or only weakly positive in controls (table 4). Most of the children with TDS also showed weak or absent epithelial staining with HLA-DR, although one child showed strong positive staining. VLA-1 expression showed a similar pattern, with no difference between the controls and patients (table 4).

\section{Epithelial cell proliferation}

The antibody $\mathrm{Ki} 67$ was used to assess epithelial cell proliferation. ${ }^{14}$ In control children $8 \cdot 2$ (SD $2.0) \%$ of the crypt epithelial cells were $\mathrm{Ki} 67$ positive. In contrast, in children with TDS, $26 \cdot 1$ (SD 4.5 ) $\%$ of the cells were Ki67 positive, indicating a three-fold increase in cell proliferation.

Discussion

We provide here a detailed histopathological

Table 4 HLA-DR and VLA-1 expression on caecal epithelium

\begin{tabular}{|c|c|c|c|c|}
\hline & \multicolumn{2}{|c|}{$H L A-D R$ expression } & \multicolumn{2}{|c|}{$V L A-1$ expression } \\
\hline & \multicolumn{4}{|c|}{ Location of epithelium } \\
\hline & Surface & Crypt & Surface & Crypt \\
\hline \multicolumn{5}{|c|}{ Controls } \\
\hline 1 & & \pm & ++ & + \\
\hline 2 & + & \pm & + & \pm \\
\hline 3 & - & 二 & \pm & \pm \\
\hline 4 & + & - & $\bar{t}+$ & \pm \\
\hline 5 & - & - & $++t$ & + \\
\hline 6 & ++ & - & ++ & + \\
\hline \multicolumn{5}{|c|}{ Patients } \\
\hline 1 & - & - & + & \pm \\
\hline 2 & \pm & + & +++ & \pm \\
\hline 3 & $=$ & - & + & $\overline{ \pm}$ \\
\hline 4 & \pm & \pm & + & $\bar{t}$ \\
\hline 5 & $\bar{t}+$ & $\overline{ \pm}$ & - & - \\
\hline 6 & +++ & $\bar{t}$ & +++ & + \\
\hline 7 & + & \pm & ++ & + \\
\hline 8 & + & $\bar{z}$ & \pm & \pm \\
\hline 9 & ++ & \pm & $\bar{t}+$ & \pm \\
\hline 10 & - & $\bar{z}$ & +++ & $\bar{t}$ \\
\hline 11 & \pm & \pm & \pm & - \\
\hline
\end{tabular}

- , no staining; \pm , very weak staining; + , clearly positive, but weak; ++ , moderately positive; ,+++ strongly positive. and immunohistological study of the caecal mucosa in children with trichuriasis. A principal observation is that despite the presence of heavy worm burdens, and the passage of frequent bloody mucoid diarrhoeal stools, there is little evidence of an inflammatory response in the colonic mucosa, apart from in the immediate vicinity of the worm, where epithelial damage does occur. These studies confirm an earlier necropsy report on two children with massive trichuriasis (as well as other disorders). ${ }^{15}$ In a review of trichuriasis, Pawlowski mentioned that infiltration of lymphocytes, plasma cells, and eosinophils is seen in heavy infections with Trichuris trichiura, but no illustrations or quantitative data were presented. ${ }^{16}$ Here we show that using standard histopathological features it was impossible to attribute the cellular infiltrate seen in the colon to Trichuris as most of the control children had the same changes.

The mild non-specific inflammatory changes in the caecum of Jamaican control children, in the absence of any kind of colonic disease, is perhaps surprising (such as cases 1 and 4 in table 1). At colonoscopy these children did not have any worms in their caeca. It is unlikely that they would have been missed for the worms are $4-5 \mathrm{~cm}$ long and are easily visible through the endoscope. We, of course, cannot rule out the possibility that the controls were recovering from mild trichuriasis and had just eliminated their worms. The prevalence of $T$ trichiura in children in western Jamaica is $55 \%,{ }^{17}$ but figures for Kingston and the surrounding rural areas are not available. Most children also only harbour a few worms. ${ }^{23}$ The best explanation for the increased inflammatory infiltrate in the control children is that it reflects the poor standards of hygiene and the contaminated environment in which they live, which in turn reflects the low socioeconomic status of most of the children.

Bloody diarrhoea in the developed world is often associated with the idiopathic colitides, ulcerative colitis or Crohn's colitis. None of the features characteristic of these disorders, ${ }^{18} 19$ however, such as crypt abscesses in ulcerative colitis, or a dense lymphocytic infiltrate and granulomata of Crohn's colitis, was apparent in the mucosa of the children with trichuriasis. The mucoid diarrhoea is undoubtedly due to increased mucus secretion. We have shown that increased crypt cell proliferation is indicative of increased cell production and turnover in the colon of these children. It is known that immune complexes and $\operatorname{IgE}$ mediated anaphylaxis in the gut can cause increased release of mucus from goblet cells. ${ }^{2021}$ Children with trichuriasis have high titres of IgG, IgM, and IgE antibodies to Trichuris in their serum, ${ }^{22}$ so it is possible that these humoral events are important in goblet cell secretion. Increased epithelial crypt proliferation in the gut can be induced by activated $T$ cells in the lamina propria, ${ }^{8}$ but this is unlikely to account for the increased proliferation seen in trichuriasis because activated $T$ cells were uncommon in the lamina propria. A more likely explanation is that worm damage to the surface 
epithelial cells induces a compensatory increase in crypt cell proliferation.

The blood in the stools of the children probably leaked out from areas where the worm head had burrowed into the mucosa, because no ulcers were seen in the mucosa. It has been shown, however, that blood loss in trichuriasis is only $5 \mu \mathrm{l} /$ worm/day, ${ }^{23}$ so that in a child with 1000 worms only $5 \mathrm{ml}$ would be lost a day. It is difficult to explain how such a small volume could cause overtly bloody stools. Electron microscopical examination shows that erythrocytes can be seen to cross intact large bowel epithelium in mild ulcerative colitis. ${ }^{24}$ Perhaps non-specific increased colonic blood flow in trichuriasis could result in red cell leakage from the sub-epithelial vascular arcades and across the epithelium. Electron microscopical studies are currently under way to address this problem.

Animal experiments have shown that $\mathrm{T}$ cells have an important role in defence against parasitic nematodes. ${ }^{25} \mathrm{We}$ had therefore expected to identify activated $T$ cells around the anterior end of the worm embedded below the epithelium. This, however, was not the case. T cell numbers in the lamina propria were the same in controls and childred infected with Trichuris, even in the areas around the worm head, and activated $T$ cells were rather uncommon in most of them. Because Trichuris trichiura lives with its anterior end buried within the colonic epithelium we considered that the parasite might induce an intraepithelial $\mathrm{T}$ cell infiltrate, but this was not the case and the numbers of these cells were actually reduced in the infected children. This could be due to increased loss of intraepithelial cells into the lumen or decreased migration into the epithelium.

There has been intense interest in cells expressing the $\gamma \delta \mathrm{TcR}+$ in the gut epithelium in recent years. In man these cells only constitute about $10 \%$ of the CD3 + intraepithelial cells; but this proportion is increased in untreated coeliac disease. ${ }^{26-28}$ There are also increased numbers of $\gamma \delta \mathbf{T c R}+\mathbf{T}$ cells in the chronic lesions of leprosy and leishmaniasis. ${ }^{29}$ Intraepithelial $\gamma \delta \mathrm{TcR}+\mathrm{T}$ cells, however, were also decreased in children with TDS.

Taking all the results together, there was little immunohistological evidence for a local inflammatory response in the mucosa. IgA and IgG plasma cell numbers were the same as in controls, although there was a slight increase in IgM plasma cells; $T$ cell numbers were the same; and the stigmata of local immune reactions seen in the idiopathic colitides, such as increased epithelial HLA-DR and VLA-1 expression, were not apparent. This suggests that there is no cell mediated anti-parasite mechanism operating in the mucosa of these children. There is in fact no evidence for acquired immunity to Trichuris. The children with TDS may be a selected population: their heavy worm burdens may result from failure to mount a protective response (as opposed to a serum antibody response which may be of no protective value). On the other hand, the children with heavy infestations may merely be the ones who are exposed to a lot of eggs. Studies are in progress to determine if children with TDS have parasite specific $T$ cells in their blood and colonic lamina propria.

In conclusion, our findings concur with previous descriptions of trichuriasis as an essentially non-pathological helminthic infestation. ${ }^{30}$ The children examined in this study were selected in the sense that they had exceptionally high worm burdens which caused TDS and growth retardation. Even in these selected children, however, the colonic immunopathological changes were minimal. Why the antigenic load of hundreds and sometimes thousands of metabolically active, 4-5 cm long, metazoan parasites living with their heads buried in the colonic epithelium should fail to elicit mucosal inflammation is of extreme interest and is the subject of ongoing studies.

This work was supported by the Wellcome Trust.

1 Ramsey FC. Trichuris dysentery syndrome. West Ind Med J 1962;11:235-9.

2 Bundy DAP. Epidemiological aspects of Trichuris and trichuriasis in Caribbean communities. Trans $R$ Soc Trop Med Hyg 1986;80:706-18.

3 Bundy DAP, Cooper ES. Trichuris and trichuriasis in humans. Adv Parasitol 1989;28:107-73.

4 Cooper ES, Bundy DAP, MacDonald TT, Golden MHN. Growth suppression in the Trichuris dysentery syndrome. Eur J Clin Nutr 1990;44:285-91.

5 Silverman FN. Regional enteritis in childhood. Aust Paediatr J 1966;11:20.

6 O'Donogue DP, Dawson AM. Crohn's disease in childhood. Arch Dis Child 1977;52:627-32.

7 Isaacson PG, Wright DH. Immunocytochemistry of lymphoreticular tumours. Immunocytochemistry. In: Polak JM, van Noorden S, eds. Practical applications in pathology and biology. Bristol: John Wright \& Sons, 1983:249.

8 MacDonald TT, Spencer J. Evidence that activated $T$ cells play a role in the pathogenesis of enteropathy in human small intestine. J Exp Med 1988;167:1341-9.

9 Choy M-Y, Walker-Smith JA, Williams CB, MacDonald TT. Differential expression of CD25 on mucosal T cells and macrophages distinguishes the lesions in ulcerative colitis and Crohn's disease. Gut 1990;31:1365-70.

10 Selby WS, Janossy G, Mason DY, Jewell DP. Expression of HLA-DR antigens by colonic epithelium in inflammatory bowel disease. Clin Exp Immunol 1983;53:614-18.

11 Scott $\mathrm{H}$, Sollid LM, Fausa $\mathrm{O}$, et al. Expression of major histocompatability Class 11 subregion products by jejunal epithelium in patients with coeliac disease. Scand $J$ Immunol 1987;26:563-71.

12 MacDonald TT, Weinel A, Spencer J. HLA-DR expression in fetal human small intestinal epithelium. Gut 1988;29:1342-8.

13 MacDonald TT, Horton MA, Choy MY, Richman PI. Increased expression of the laminin/collagen receptor (VLA-1) on epithelium of inflamed human intestine. J Clin Pathol 1990;43:313-15.

14 Gerdes J, Lemke H, Baisch H, Wacker H-H, Schwab U, Stein $\mathbf{H}$. Cell cycle analysis of a cell proliferationassociated human nuclear antigen defined by the monoassociated human nuclear antigen defined by the mon

5 Hartz PH. Histopathology of the colon in massive trichocephaliasis in children. Doc Med Georg Trop 1953;5:303-13.

16 Pawlowski ZS. Trichuriasis. In: Adel AF Mahmoud, Warren KS, Warren S, eds. Tropical and geographical medicine. New York: McGraw Hill, 1984:380-5.

7 Speed JC, Culpepper V, Thompson DE, Henson R, Wint B, Bundy DAP. A community based study of gastrointestina helminth and protozoan infection in western Jamaica. West Ind Med J 1987;36:73-5.

18 Rappaport H, Burgoyne FH, Smetana HF. The pathology of regional enteritis. The Military Surgeon 1951;109: of regional.

19 Lockhart-Mummery HE, Morson BC. Crohn's disease (regional enteritis) of the large intestine and its distinction from ulcerative colitis. Gut 1960;1:87-105.

20 Lake AM, Bloch KJ, Sinclair KJ, Walker WA. Anaphylactic release of intestinal goblet cell mucus. Immunology 1980;39:657-65.

21 Walker WA. Role of the mucosal barrier in antigen handling in the gut. In: Brostoff J, Challacombe SB, eds. Food allergy and intolerance. London: Baillière Tindall,

22 Bundy DAP, Bianco AE, Lillywhite JE, Didier JM, Simmons I. Human antibody responses to Trichuris 
trichiura: age-dependency of infection status and serum antibody level. Trans $R$ Soc Trop Med Hyg (in press)

23 Layrisse M, Aparcedo L, Martinez-Torres C, Roche $M$ Blood loss due to infection with Trichuris trichiura. Am J Trop Med Hyg 1967;16:613-19.

24 Donnellan WL. Early histological changes in ulcerative colitis: a light and electron microscopic study. Gastrocolitis: a light and electron

25 enterology 1966;50:519-40. cells in immunity to a nematode parasite. Transplant Rev cells in immunity

26 Spencer J, Isaacson PG, Diss TC, MacDonald TT. Expression of disulphide linked and non-disulphide linked forms of the T cell receptor gamma/delta heterodimer in human intestinal intraepithelial lymphocytes. Eur J Immunol 1989;19:1335-9.
27 Halstensen TS, Scott $\mathbf{H}$, Brandtzaeg $P$. Intraepithelial T cells of the $\mathrm{T} c \mathrm{R} \gamma \delta \mathrm{CD} 8$ - and $\mathrm{V} \delta 1 / \mathrm{J} \delta 1+$ phenotypes are increased in coeliac disease. Scand $J$ Gastroenterol 1989;30:665-72.

28 Jarry A, Cerf-Bensussan N, Brousse N, Selz F, Guy-Grand $D$. Subsets of CD3 + T cell receptor $(\alpha \beta$ or $\gamma \delta)$ and CD3 lymphocytes isolated from normal human gut epithelium display phenotypical features different from their counterparts in peripheral blood. Eur J Immunol 1990;20: parts in

29 Modlin RL, Pirmez C, Hofman FM, et al. Lymphocytes bearing antigen-specific $\gamma \delta$ T-cell receptors accumulate in human infectious disease lesions. Nature 1989;339:544-8. 30 Warren KS, Mahmoud AAF. Algorithms in the management and diagnosis of exotic diseases. IX. Trichuriasis. J Infect Dis 1976;133:240-3.

\section{Eponym in pathology ...}

von LEYDIG, Franz (1821-1908) was a German comparative anatomist, born in Rothenburg. He qualified from Wurzburg in 1844. He was first a lecturer in Wurzburg, then, in 1855, was appointed professor of anatomy. In 1857 he moved to Tubingen and in the same year he described the interstitial cells of the testis (Leydig cells). In 1875 he was appointed professor of comparative anatomy at Bonn, a field in which he was a pioneer. von KUPFFER, Kar1 Wilhelm (1829-1902) was a German anatomist and embryologist, born in Munich. He was professor of anatomy successively at Kiel (1867), Koenigsburg (1875), and Munich (1880). It was while in Koenigsburg in 1876 that he first described the stellate cells lining the sinusoids of the liver (Kupffer cells). As well as this, he made important contributions to embryology, and the embryonic outgrowths from the Wolffian ducts which form the ureters also bear his name. 